\title{
DEVELOPMENT OF METHODICAL MAINTENANCE OF DECISION SUPPORT PROCESS AUTOMATED CONTROL PRODUCTION
}

\author{
G.G. Kulikov', E.A. Dron ${ }^{1 *}$, S.G. Kulikov² \\ ${ }^{1}$ Ufa State Aviation Technical University, Ufa, \\ ${ }^{2}$ IT-Department in Economic Agency, Ufa \\ *elena_dron@bk.ru
}

\begin{abstract}
The article suggests a complex system models of industrial enterprises, which connect with the object management. These models allow us to construct a single circuit management of expenses on the responsibility centers with decomposition on hierarchical levels. The article presents valuation model optimal point in time for the formation of control actions based on Kolmogorov differential equations. This mathematical model allows us to implement the principle of coordinating actions to manage costs in the abnormal production situations. This model allows you to define the consequences functions of taken decisions using functional and cost analysis. The article describes technique of creation of decision-making support procedures in emergency production situations on the expenses model system. This model formalizes knowledge of domain data experts. The model need to automate functions of intellectual control.

Keywords: system project, cost management, responsibility center, ERP-system, decision making support system.
\end{abstract}

\section{Introduction}

Effective management of production represents the complex multivariate challenge in the analysis and estimates of production situations, determination of control strategy. In the modern conditions of development of production there are some requirements to qualitative characteristics of production objects, execution of the scheduled plan and to reduction of production periods, operations, services raise. The manufacturing enterprise is characterized by the following features: this diversity resources, high complexity of production, mobility, a large number of production participants, the long production cycle, and also high susceptibility to influence of arbitrary factors.

Due to the manufacturing enterprise explained in organizational control application of ERP-system (Enterprise Resource Planning) allowing to construct a uniform circuit of expenses control is necessary. In difficult dynamic system there are internal and external perturbing influences that leads to the considerable unproductive expenses. It is connected to origin of deviations in flows of resources which have accidental character on time and quantity. As a result of it the sequence of performance of work is broken, there are deviations from the scheduled plan of all interdependent operations.

Therefore application of Enterprise resource planning is necessary, but there isn't enough for effective management of production in which there is large volume of unproductive expenses. Creation of the automated decision making support system integrated with Enterprise resource planning on the basis of formalization of expert knowledge and application of mathematical models is necessary.

\section{Creation of system model of organizational control of manufacturing enterprise}

The technique is developed for survey and formalization of information flows in organizational control construction production. In this technique the method of indistinct classification and coding of information is used.

The technique of indistinct classification and coding of information allows to support requirements to implementation of paper and electronic document flow. Also this technique is applied to automation of project management functions. Systems of classification of coding of information it was developed. This classification is necessary for carrying out preproject survey and development of the system project of the information managing director of system. The technique of classification of technical and economic information of organizational document flow in the enterprises is result. When carrying out survey of the functional activities of the enterprise 14 functional subsystems are revealed. Subsystems include 60 processes of activities and 250 functions of activities, the register of documents contains about 


\section{Краткие сообщения}

one thousand documents. System simulation of production and administrative activity was executed on the basis of preproject survey. Also standard circuit of control of expenses was simulated on methodology of structural analysis and design of SADT.

The analysis of a standard circuit of control of expenses showed need of separation of centers of responsibility according to requirements of business processes of the organization and with functions of the regular management. Decomposition of responsibility centers functions $f$ of the enterprise allows to select expenses centers at the enterprise.

The developed control production model includes: responsibility centers separation on the basis of organization structure conjugation system model of administrative activities; the formalized description of expenses centers mechanisms on the basis of conjugation of system model of production activity for levels of operations (such, as, single operation, a complex of operations, an object, building); subsystem of an electronic document management. The developed diagrams of document flow allow to define a route of formation of the operational accounting of factor and unproductive cost in codes of documents and to create the diagram of an electronic document management satisfying Enterprise resource planning methodologies.

The analysis showed that on modules "Expenses Control", "Production" it is necessary to develop system models of the process flows (PF), the working centers (WC) and expenses centers of (ES) for functioning of Enterprise resource planning. The analysis of conditions of the formalized descriptions of PF, WC applied to expenses control in ERP systems is for this purpose carried out. The formalized graphic-analytical method of simulation of a process flow, working center is developed with use of these models.

The technique of formation of process flows, working centers, centers of expenses consists of the following main stages:

1. Requirement analysis of the ERP concept.

2. Survey of administrative and production activity of the enterprise.

3. Creation of system model of productions of the enterprise, on the basis of technological documentation to the level of technological operation.

4. Creation of a mathematical model of production and administrative processes of the enterprise on the basis of functional value analysis.

5. The analysis and formalization of levels and indices of expenses management system on the basis of system model of administrative activities.

6. The analysis and formalization of process flows, centers of expenses, working centers in case of execution of production operations.

7. Conversion of process flows models, expenses centers, working centers on the basis of rules of the equivalent conversion in compliance with requirements and classification of ERP.

Let's consider rules of the equivalent conversion of process flows, expenses centers, working centers according to requirements and classification of ERP:

1. Compilation of the register of working centers, process flows, technological operations.

2. The analytical description of technological operations on the basis of ABC-analysis.

3. Creation of standard, group, alternative working centers, process flows, technological operations.

4. Coding of working centers, process flows, technological operations.

The function and dynamic models of process flows are constructed, ABC analysis for the accounting of unproductive expenses is carried out, and the research of compliance of properties of process flows in production and in ERP methodology is conducted. Information sufficiency of analytical indices of process flows in production is shown. The method of element structurization is applied to create system models of expenses centers, working centers on the basis of the analysis of process flows. This method allows to analyze resources. The technique of formation of working centers, expenses centers according to methodology of ERP systems was as a result offered. The production management model including is offered: separation of centers of responsibility on the basis of conjugation of an organization structure and system model of administrative activities; the formalized description of mechanisms of expenses centers on the basis of conjugation of system model of production activity for levels of operations; subsystem of an electronic document management.

\section{Formalization of intellectual activities of production experts}

On the basis of the developed heuristic model of unproductive expenses control the conclusion is drawn that during the shift in real production systems there is at the same time a set of deviations of the current parameter values from resources, plan on different types. Classification of classes of the emergency situations 
arising when working, also losses from these situations and expert estimates are given in Table 1. Six main classes of emergency production situations which are divided into 16 subclasses are selected.

The mathematical model of assessment of timepoint for formation of effective administrative solutions formalizing the principle of the coordinating influences is developed.

Classification of emergency situations

Table 1

\begin{tabular}{|c|c|c|}
\hline № & Name of a situations class & $\begin{array}{ll}\text { Situations signs } \\
\end{array}$ \\
\hline \multirow[t]{4}{*}{1} & \multirow{4}{*}{$\begin{array}{l}\text { Untimely provision of a scope } \\
\text { of work from one performer }\end{array}$} & 1.1. Time delays in connection with poor quality \\
\hline & & $\begin{array}{l}\text { 1.2. Absence of strictly regulated diagram of reception delivery } \\
\text { of fronts of operations }\end{array}$ \\
\hline & & $\begin{array}{l}\text { 1.3. Untimely provision of fronts of operations by the previous } \\
\text { performer }\end{array}$ \\
\hline & & 1.4. Violation of labor discipline \\
\hline 2 & $\begin{array}{l}\text { Interruptions in arrival } \\
\text { of the material resources }\end{array}$ & 2.1. Interruptions in arrival of construction materials \\
\hline \multirow[t]{3}{*}{3} & \multirow[t]{3}{*}{ Failures of the chief suppliers } & 3.1. Short delivery of panels \\
\hline & & 3.2. Delivery of the panels which aren't corresponding to quality \\
\hline & & 3.3. Breakage and failure of the equipment \\
\hline \multirow[t]{3}{*}{4} & \multirow{3}{*}{$\begin{array}{l}\text { Failures of the motor transportation } \\
\text { enterprise }\end{array}$} & 4.1. Breakage and failure of the equipment \\
\hline & & 4.2. Nonrational use of power of a motor transport \\
\hline & & 4.3. Low level of the organization of repair economy \\
\hline \multirow[t]{4}{*}{5} & \multirow{4}{*}{$\begin{array}{l}\text { Breakages of machines mechanisms } \\
\text { during operation }\end{array}$} & 5.1. Breakages of machines and mechanisms \\
\hline & & 5.2. Untimely submission of requests \\
\hline & & 5.3. Untimely repair \\
\hline & & 5.4. Violation of specifications of operation \\
\hline 6 & $\begin{array}{l}\text { Unfavorable weather climatic } \\
\text { conditions }\end{array}$ & 6.1. Unfavorable weather climatic conditions \\
\hline
\end{tabular}

It is this: a set of chance fluctuations of the productions flowing from reference (plan) parameter values.

Assumptions: The controlling system represents Markov process. Transitions to a status come from a status under the influence of Poisson event streams.

Reduction of unproductive expenses on production is connected, first of all, to the sequence of execution by normative validity of the used resources for creation of space of reference values of controlled parameters of productions. Primacy of an order of the performed works before value of the selected resources in emergency production situations is a necessary condition for implementation of the principle of the coordinating influences in case of control of expenses in construction. Determination of points of phase transition of the controlling system from one qualitative status in other status belongs to its sufficient condition.

In operation it is offered in case of control of expenses to apply differential equations of Kolmogorov to simulation of key parameters of the coordinating influences. This model allows to evaluate timepoint for decision-making (from the point of view of unproductive expenses):

$$
\begin{array}{cc}
P_{1}(t)=\frac{\mu}{\lambda+\mu}+\frac{\lambda}{\lambda+\mu} e^{-(\lambda+\mu) t} & P_{2}(t)=1-P_{1}(t)=\frac{\lambda}{\lambda+\mu}\left(1-e^{-(\lambda-\mu) t}\right) \\
t=-\frac{1}{2(\lambda+\mu)} \ln \frac{\lambda-\mu}{\lambda} & \\
\lambda=\lambda_{F}+\lambda_{L}+\lambda_{M}+\lambda_{I} ; & \mu=\mu_{F}+\mu_{L}+\mu_{M}+\mu_{I} . \\
P_{l M}=e^{-\lambda M t} ; & P_{2 M}=1-e^{-\ell M M t} . \\
P_{I S}(t)=P_{I F}+P_{l L}+P_{I M}+P_{I I} ; & P_{I S}(t)=P_{I F}+P_{I L}+P_{I M}+P_{I I} \\
\lambda_{M}=\sum_{i=1}^{n} \sum_{j=1}^{4} \lambda_{i, M} & M_{M}=\sum_{i=1}^{n} \sum_{j=1}^{4} \mu_{l, M}
\end{array}
$$




$$
P_{1 M}=\sum_{i=1}^{n} \sum_{j=1}^{4} e^{-\left(\lambda_{M i j}\right) t}, \quad P_{2 M}=\sum_{i=1}^{n} \sum_{j=1}^{4}\left(1-e^{-\left(\lambda_{M i j}\right) t}\right)
$$

where $S_{1}$ - system status class in case of sufficient support of resources;

$S_{2}$ - system status class in the absence of schedulable resources;

$P_{1}(t), P_{2}(t)$ - probabilities of a status of system with planned targets of resources and in the absence of schedulable resources;

$t$ - time to which it is necessary to create the administrative decision for elimination of an emergency production situation;

$\lambda$ - the intensity translating system from a status $S_{1}$ to $S_{2}$;

$\mu$ - the intensity translating system from a status $S_{2}$ to $S_{1}$;

$S_{F}, S_{L}, S_{M}, S_{I}$ - subclasses of the statuses characterizing existence of types of resources $I$;

$\lambda_{F}, \lambda_{L}, \lambda_{M}, \lambda_{I}-$ intensity of event streams of subclasses;

$P_{I M}, P_{2 M}$ - probability of a subclass of statuses;

$\lambda_{M i j}$ - intensity of a flow of accidental events for groups of subclasses.

For minimization of the unproductive expenses connected to untimely acceptance of the administrative decision in an emergency production situation we find critical points of phase transition of the managing director of system from one status in another. At the same time two classes of statuses of the managing director of system, subclasses, and also groups of subclasses are considered.

Diagrams of change of probabilities in time of statuses of the controlling system for classes of situations $S_{1}$ and $S_{2}$, and also for different subclasses are provided on Fig. 1,2. On the basis of statistical data of the construction organizations the frequency of appearance of events and intensity $\lambda$ is defined and optimum timepoint of $t_{\mathrm{opt}}$.
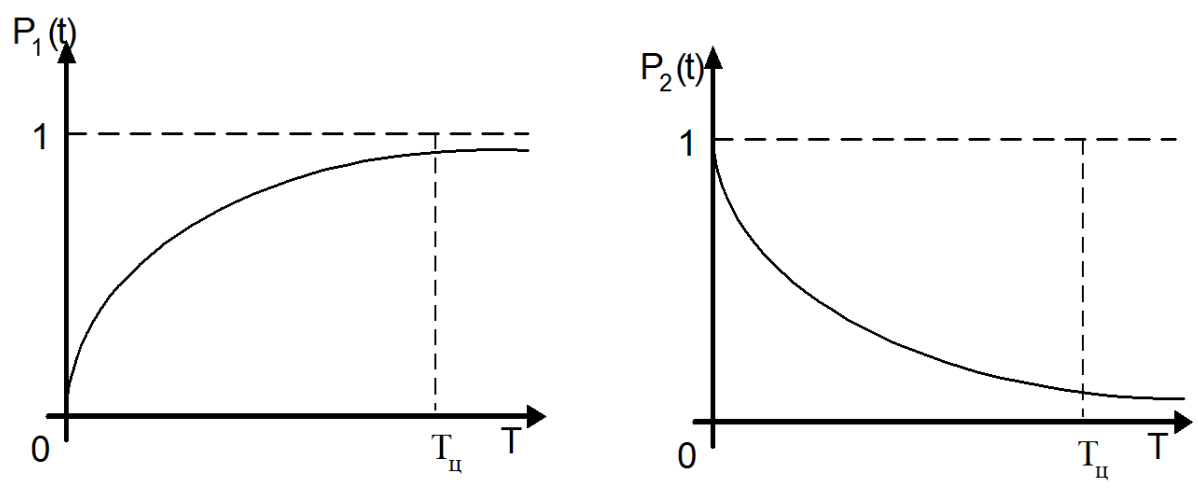

Fig. 1. Change of probabilities of statuses of the controlling system in case of the perturbing influences

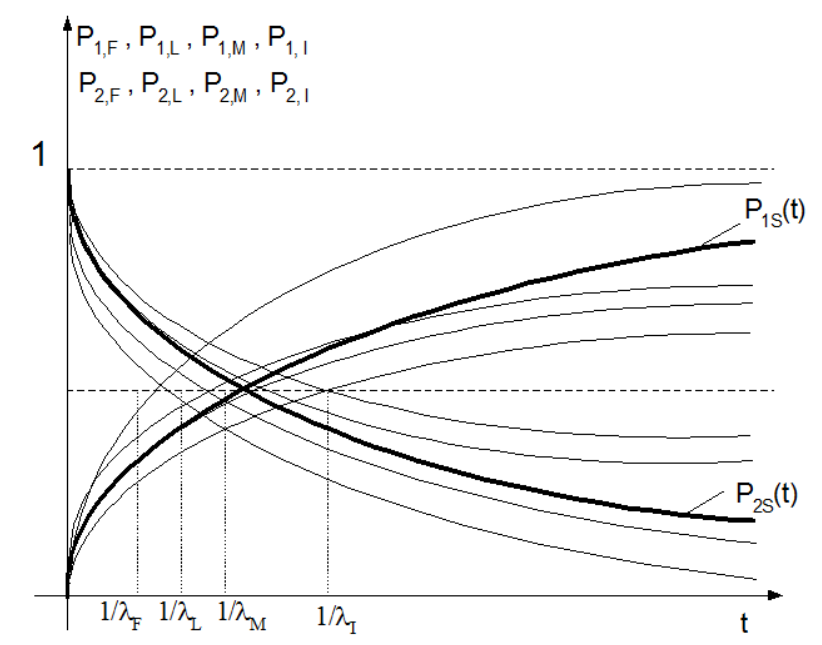

Fig. 2. Change of probabilities of statuses of the controlling system in case of the perturbing influences 
The algorithm of support of decision-making in case of control of expenses in emergency production situations is built on the basis of use of the principle of the coordinating influences and creation of function of consequences taking into account optimum timepoint for formation of the controlling influences. On the basis of an algorithm the optimum strategy of control directed to minimization of unproductive expenses of the persons making decisions at the different levels of organizational control are defined (the masters, the foreman, the high foreman, the chief engineer, the director).

\title{
Conclusion
}

System models of activities of the production enterprise with detailing to product model (production object), and also formalization model of a process flow, working center are considered. The analysis of functioning of Enterprise resource planning is carried out, it is shown that the decision making support system in addition is required. In operation it is offered in case of control of expenses to apply differential equations of Kolmogorov to simulation of key parameters of the coordinating influences that allows to realize the principle of the coordinating influences in case of control of expenses in emergency production situations and to define functions of consequences from the made decisions.

\section{References}

1. Dron' E.A. [Decision Support System in the Construction Management of the System Cost Models.]. Bulletin of the Ufa State Aviation Technical University, 2010, vol. 5, no. 2 (37), pp. $220-227$. (in Russ.)

2. Antonov V.V., Kulikov G.G., Antonov D.V. Teoreticheskie i prikladnyie aspektyi postroeniya modeley informatsionnyih sistem [Theoretical and Applied Aspects of Building Models of Information Systems]. LAP LAMBERT Academic Publishing, Germany, 2011. 134 p.

3. Rechkalov A.V., Artyuhov A.V., Antonov V.V. [Development of a Formal Model of an Integrated Production Process Engineering Enterprise]. Bulletin of the Ufa State Aviation Technical University, 2010, vol. 18, no. 4 (65), pp. 125-133. (in Russ.)

4. Kulikov G.G., Dron’ E.A., Bagaeva Yu.O., Shilina M.A. Avtomatizirovannyie informatsionnyie sistemyi v ekonomike: uchebnoe posobie [Automated Information Economic Systems: Manual]. Ufa, USATU, 2013. $180 \mathrm{p}$.

Received 24 August 2016

\section{РАЗРАБОТКА МЕТОДИЧЕСКОГО ОБЕСПЕЧЕНИЯ ПРОЦЕССОВ ПОДДЕРЖКИ ПРИНЯТИЯ РЕШЕНИЙ В АВТОМАТИЗИРОВАННОМ УПРАВЛЕНИИ ПРОИЗВОДСТВОМ}

\author{
Г.Г. Куликов ${ }^{1}$, Е.А. Дронь ${ }^{1}$, С.Г. Куликов ${ }^{2}$ \\ ${ }_{1}^{1}$ Уфимский государственный авиационный технический университет, г. Уфра, \\ ${ }^{2}$ Министерство экономического развития Республики Башкортостан, г. Уфра
}

Разработан комплекс системных моделей производственного предприятия, во взаимосвязи с объектом управления, что позволяет построить единый контур управления затратами по центрам ответственности с декомпозицией по иерархическим уровням. Разработана модель оценки оптимального момента времени для формирования управляющих воздействий на основе дифференциальных уравнений Колмогорова. Она позволяет реализовать принцип координирующих воздействий при управлении затратами в нештатных производственных ситуациях и определить функции последствий от принятых решений на основе функциональностоимостного анализа работ. Разработана методика построения процедур поддержки принятия решений в нештатных производственных ситуациях на основе системной модели затрат, 


\section{Краткие сообщения}

которая позволяет формализовать знания специалистов предметной области и автоматизировать функции интеллектуального управления.

Ключевые слова: системный проект, управление затратами, центр ответственности, ERP-системы, системы поддержки принятия решений.

\section{Литература}

1. Дронь, Е.А. Система поддержки принятия решений при управлении строительством на основе системной модели затрат / Е.А. Дронь, С.Г. Куликов // Вестник УГАТУ. - 2010. - Т. 5, № 2 (37). - C. 220-227.

2. Антонов, В.В. Теоретические и прикладные аспекты построения моделей информационных систем / В.В. Антонов, Г.Г. Куликов, Д.В. Антонов. - LAP LAMBERT Academic Publishing, Germany, 2011. - 134 c.

3. Речкалов, А.В. Разработка формальной интегральной модели производственного процесса машиностроительного предприятия / А.В. Речкалов, А.В. Артюхов, В.В. Антонов // Вестник УГАТУ. - 2010. - Т. 18, № 4 (65). - C. 125-133.

4. Автоматизированные информационные системы в экономике: учеб. пособие / Г.Г. Куликов, Е.А. Дронь, Ю.О. Багаева, М.А. Шилина. - Уфа: УГАТУ, 2013. - 180 с.

Куликов Геннадий Григорьевич, д-р техн. наук, профессор кафедры автоматизированных систем управления, Уфимский государственный авиационный технический университет, г. Уфа.

Дронь Елена Анатольевна, канд. техн. наук, доцент кафедры автоматизированных систем управления, Уфимский государственный авиационный технический университет, г. Уфа; elena dron@bk.ru.

Куликов Сергей Геннадьевич, ведущий специалист отдела координации государственных закупок Министерства экономического развития Республики Башкортостан, г. Уфа.

Поступила в редакцию 24 августа 2016 г.

\section{ОБРАЗЕЦ ЦИТИРОВАНИЯ}

Kulikov, G.G. Development of Methodical Maintenance of Decision Support Process Automated Control Production / G.G. Kulikov, E.A. Dron, S.G. Kulikov // Вестник ЮУрГУ. Серия «Компьютерные технологии, управление, радиоэлектроника». - 2016. - Т. 16, № 4. C. $143-148$. DOI: $10.14529 /$ ctcr160417

\section{FOR CITATION}

Kulikov G.G., Dron E.A., Kulikov S.G. Development of Methodical Maintenance of Decision Support Process Automated Control Production. Bulletin of the South Ural State University. Ser. Computer Technologies, Automatic Control, Radio Electronics, 2016, vol. 16 , no. 4 , pp. 143-148. DOI: $10.14529 /$ ctcr160417 